\title{
Analysis of Lifestyle, Advertising Effectiveness, and Instant Coffee Consumption among Peri-Urban Farmers
}

\author{
Moh. Djemdjem Djamaludin ${ }^{1 *}$, Dewi Mutia Silmie ${ }^{2}$ \\ ${ }^{1,2}$ Department of Family and Consumer Sciences, Faculty of Human Ecology, \\ IPB University, Bogor 16680, Indonesia
}

*Corresponding author: moh.dj@apps.ipb.ac.id

\begin{abstract}
Coffee consumption is increasing because many types of coffee are circulating, such as instant coffee among the public. The instant coffee studied in this study is the Iwan Fals edition of instant coffee. This study aimed to analyse the lifestyle and effectiveness of instant coffee advertising on instant coffee consumption among peri-urban farmers in Bogor Regency. This study used a crosssectional study design located in Cibungbulang District, Bogor Regency. The location was chosen purposive because it is a peri-urban area that has more than $20 \%$ of agricultural land. A total of 100 respondents in this study were selected using a purposive sampling method with the criteria of a farmer and in the last 12 months consuming and viewing Iwan Fals edition coffee advertisements. The results of this study found that the maker's lifestyle is the most (32\%) owned by the respondents. The effectiveness of instant coffee advertising in this study is included in the effective category (3.54). The results showed a relationship between gender, believing lifestyle, trying hard lifestyle with instant coffee consumption. The influence test results found an influence of male gender and lifestyle beliefs on instant coffee consumption. In general, respondents are classified as effective in consuming coffee because of their lifestyle and increase energy.
\end{abstract}

Keywords: advertisement effectiveness, consumption of coffee, farmers, instant coffee, lifestyle

\begin{abstract}
Abstrak
Konsumsi kopi saat ini mengalami peningkatan salah satunya karena sudah banyaknya jens kopi yang beredar seperti kopi instan di kalangan masyarakat. Kopi instan yang diteliti dalam penelitian ini adalah kopi instan (edisi Iwan Fals). Tujuan dalam penelitian ini adalah untuk menganalisis gaya hidup dan efektivitas iklan kopi instan terhadap konsumsi kopi instan di kalangan petani peri-urban Kabupaten Bogor. Penelitian ini menggunakan desain cross sectional study, berlokasi di Kecamatan Cibungbulang, Kabupaten Bogor. Pemilihan lokasi secara purposive karena merupakan wilayah peri-urban yang memliki lahan luas pertanian lebih dari $20 \%$. Sebanyak 100 orang responden dalam penelitian ini dipilih menggunakan metode purposive sampling dengan kriteria seorang petani dan dalam 12 bulan terakhir mengonsumsi dan melihat iklan kopi (edisi Iwan Fals). Hasil penelitian ini menemukan bahwa gaya hidup pembuat paling banyak (32\%) dimiliki oleh responden. Efektivitas iklan kopi instan pada penelitian ini termasuk dalam kategori efektif (3.54). Hasil penelitian menunjukan adanya hubungan antara jenis kelamin, gaya hidup percaya, gaya hidup berusaha keras dengan konsumsi kopi instan. Hasil uji pengaruh menemukan adanya pengaruh jenis kelamin laki-laki dan gaya hidup percaya terhadap konsumsi kopi instan. Secara umum responden tergolong efektif dalam opi mengonsumsi karena gaya hidup maupun untuk menambah energi.
\end{abstract}

Kata kunci: efektivitas iklan, gaya hidup, konsumsi kopi, kopi instan, petani 


\section{Introduction}

In the last decade, there has been an increase in national coffee production. The increase in coffee production can be seen from the increasing number of land areas and Indonesia's coffee industry development. In Indonesia, the increase in coffee area from 2011 to 2016 was in line with the increase in coffee production (Ministry of Agriculture, 2017). Data from the Indonesian Coffee Exporters Association (AEKI) (2013) shows that coffee consumption in Indonesia has increased continuously, in 2015 by $1.09 \mathrm{~kg}$ per capita per year, increasing to $1.15 \mathrm{~kg}$ per capita per year in 2016. In addition, the Ministry of Industry (2016) explains that national coffee consumption has grown by $10 \%$ per year for the last ten years, even though world consumption growth is only $2.5 \%$. This is in line with Swastika (2012), which says that Indonesian people's consumption of coffee has increased rapidly by $98 \%$ in the last ten years. The increase was due to changes in people's social patterns in drinking coffee, the increasingly affordable price of coffee, and the practicality of drinking coffee.

A coffee drink is a drink derived from coffee beans which are processed through the separation stage of coffee beans, roasted without being mixed with other ingredients, ground, extracted with water, and dried through an extraction process into a product that is easily soluble in water (Kemenperin, 2016). One of the most widely circulated types of coffee in the community, especially among farmers, is instant coffee. Instant coffee is a drink consumed by various groups of people, both rural communities, urban communities, and peri-urban communities. The peri-urban community is a society that is in a transitional area between villages and cities. Peri-urban communities, which farmers still dominate, often buy instant coffee as an alternative to sweet drinks for their daily nonfood needs (Yunianto, 2015).

Based on BPS data (2017), the agricultural sector is still one of the three main sectors driving the national economy after industry and trade. This shows that farmers have an important role in nation-building. However, it is unfortunate that farmers only complete elementary school education, less than six years (BPS, 2013). Education still considered lacking in farmers has resulted in farmers as end consumers vulnerable to exposure to information. For example, the information obtained by farmers in consuming instant coffee is obtained through advertisements shown on television that farmers' education is on average inadequate, with educational data.

The role of farmers as consumers in consuming coffee is also related to the information that has been obtained. The information such as advertisements aired on television indirectly displays various instant coffee advertisements (Lee \& Johnson, 2007). According to Mowen and Minor (2012), advertisements shown on television will give consumers a stimulus. Companies compete to present attractive advertisements because advertisements can motivate consumers to consider buying a brand and create strong brand associations with all the effects of stored communication to influence consumers (Kotler \& Keller, 2008). Their lifestyle and advertising influence farmers who consume instant coffee as the main source of information (Satyajaya, Rangga, Nurainy \& Al Rasyid, 2014). Advertisements received by farmers must be effective because they will provide information following the purpose of the message to be conveyed by using several elements, including endorser credibility and advertising creativity (Handoko, 2006).

Instant coffee is attractive to farmers for several reasons: affordable prices, attractive displays, packaging, price, taste, and brand (Satyajaya et al., 2014). In addition, 
there are two main motives: a drink to relieve anxiety in dealing with problems and relieve boredom, and it is suitable for gathering with friends. Coffee consumption has become a person's lifestyle (33\%) in line with research by Soikatun, Kartono, and Demartoto (2015) that drinking instant coffee is not only a necessity but has become a lifestyle. The practical lifestyle makes instant coffee consumption in great demand, especially for people who have a lot of activity (Satyajaya et al., 2014). Farmers with a lot of physical activity tend to like instant coffee as a drink to refresh the body. A person's lifestyle is related to a person's behaviour about how he lives, uses money, and takes advantage of his time (Sumarwan, 2011). Consumer lifestyles can be divided into six groups fulfilled, believers, achievers, strivers, experiencers, and makers (Willbanks, 2005). The lifestyle of farmers in drinking instant coffee with the lifestyle of non-farmers in drinking instant coffee will be different because the lifestyles of different individuals will result in different consumption behaviour of the same product.

Instant coffee (Iwan Fals edition) was chosen in this study because the coffee has a high level of promotion in Bogor Regency (Upphaswara, 2014). The existence of differences in lifestyle, advertising effectiveness, and characteristics of urban fairy farmers on instant coffee consumption encourages researchers to conduct research. Measuring an advertisement's effectiveness can use the EPIC model instrument developed by the world's leading marketing company, Ac Nielsen. Measurement with the EPIC model uses four dimensions, namely empathy, persuasion, impact, and communication. It aims to analyse the lifestyle and effectiveness of instant coffee advertising on instant coffee consumption among peri-urban farmers in Bogor Regency.

\section{Literature Review}

\section{Farmers' Demographic Characteristics of Lifestyle and Instant Coffee Consumption}

In peri-urban areas, which generally have relatively large agricultural land and easier exposure to information than rural areas, instant coffee is widely consumed by people who farmers dominate spare. Therefore, the characteristics of different farmers will lead to different consumption of instant coffee. The characteristics of farmers who consume coffee in this study consist of two dimensions. The first is demographic characteristics (age, gender, and education), while the second is economic characteristics (income). Demographic characteristics such as age, gender, education, and economic characteristics in farmers' income are thought to influence instant coffee consumption. Consumption is a shopping activity carried out to meet needs.

According to Sumarwan (2011), the consumption of products and services can be known through three things: the frequency of consumption, the amount of consumption, and the purpose of consumption. Frequency of consumption describes how often a product is used or consumed. Total consumption describes the number of products used by consumers. The purpose of consumption is the situation of use by consumers of a product with various purposes. Instant coffee consumption is influenced by several factors, including demographic and economic characteristics, lifestyle, and advertising effectiveness. This in line with the results of research by Wadi and Rahanatha (2013) that age, income, gender, and education have a relationship with instant coffee consumption. They were reinforced by Petterson and Paul (2007), Hyun et al. (2010), Wadi and Rahanatha (2013, Jung (2010) that age, income, male gender, and education can indirectly affect intentions, perceptions, and positive effects in adopting products from each 
consumer. Lifestyle is a person's behaviour about living and using time and money (Sumarwan, 2011). A person's lifestyle can be different from other people in his environment, and lifestyles tend to be permanent in a person and difficult to change in a relatively long time (Setiadi, 2008).

In addition to lifestyle, there are allegations that the effectiveness of advertising affects instant coffee consumption. Advertising is a source of information on goods and services for farmers. Advertising as a promotional medium is a form of activity to present and promote products and is non-personal (Tjiptono, 2008; Morisan, 2010). Therefore, the advertisements made must pay attention to various aspects. In line with Bram (2005), including the effectiveness is a measurement of achieving predetermined targets.

H1: Farmers' demographic characteristics affect instant coffee consumption

H2: Farmers' demographic characteristics affect their lifestyle

H3: Farmers' demographic characteristics affect the effectiveness of advertising

\section{Effect of Lifestyle on Advertising Effectiveness and Instant Coffee Consumption}

Furthermore, this study has a hypothesis that lifestyle influences the effectiveness of instant coffee advertising. This is because lifestyle will lead a person to assess the advertisements that are considered suitable for him. Furthermore, the research results of Sanjaya et al. (2014) and Handoko (2006) suggest an influence of lifestyle with instant coffee consumption. Therefore, lifestyle is related to the choice of instant coffee to be consumed to meet consumers' lifestyle needs, and effective advertising can also make consumers consume the advertised product.

H4: Lifestyle affects the effectiveness of instant coffee advertising

H5: Lifestyle affects instant coffee consumption

\section{The Effect of Instant Coffee Advertising Effectiveness on Instant Coffee Consumption}

The results of Setyawan's research (2014) show that the effectiveness of advertising is included in the category of good advertising and is quite successful in winning the hearts of the audience, easy to understand, cognitive responses, affective responses, and attitudes that support the audience themselves. It can also indirectly increase the consumption of instant coffee, one of which (Iwan Fals edition). The effectiveness of advertising can be measured using the EPIC (Empathy, Persuasion, Impact, and Communication) model proposed by Durianto (2003). The results of Hadi and Wahono's (2015) research show that based on the EPIC model, empathically advertising (Iwan Fals edition) has attracted consumers' attention to see advertisements and judged an advertisement based on its personality. Thus, persuasively attract consumers to consume, buy, and switch to instant coffee products (Iwan Fals edition). The impact also shows that it has made consumers know about instant coffee products (Iwan Fals edition) to become the main choice of purchase. In the communication section, instant coffee advertisements (Iwan Fals edition) have made consumers remember the main message and explain information about the product.

H6: The effectiveness of instant coffee advertising affects instant coffee consumption 


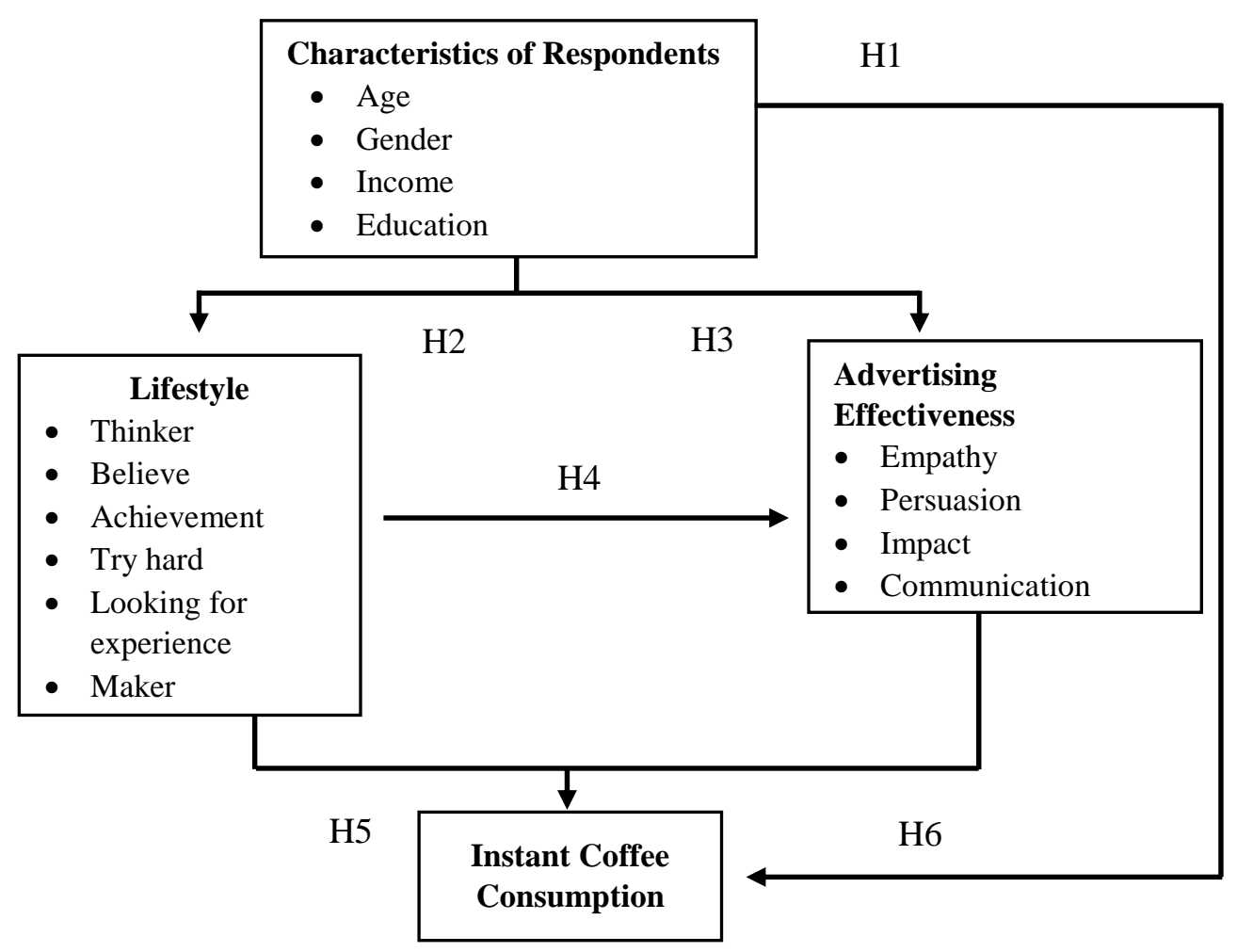

Figure 1 Conceptual framework

\section{Methods}

\section{Participants}

This study used a cross-sectional study design located in Cibungbulang District, Bogor Regency. Cibungbulang District was chosen purposively for the location of this study because peri-urban area and access are moving between villages to cities so that exposure to information such as advertisements is easily accessible. In addition, the area of Cibungbulang District has more than $20 \%$ of agricultural land. The time of the study was carried out from November 2018 to March 2019. Therefore, the population in this study are farmers who live in Cibungbulang District. Therefore, the sampling technique used in this study is a non-probability sampling technique. Furthermore, using a purposive method at the village level begins with a filtering process, namely asking whether the respondent in the last 12 months, works as a farmer, has ever drunk and seen instant coffee advertisements (Iwan Fals edition). Thus, obtained as many as 100 farmers as respondents in this study.

\section{Measurements}

The types of data collected in this study consisted of primary data and secondary data. Primary data was obtained by interviewing the respondents directly using a questionnaire containing the respondent's demographics, lifestyle, advertising effectiveness, and consumption of instant coffee (Iwan Fals edition). Meanwhile, the 
requirements to become respondents are farmers who have consumed and seen instant coffee advertisements (Iwan Fals edition) in the last 12 months.

Lifestyle is a person's spending money and time and is grouped into six categories: thinkers, believers, achievers, strivers, experience seekers, and creators. Lifestyle was measured using the VALS 2 instrument, which refers to Peter and Olson (1999) and consists of 19 statement items (Cronbach's alpha 0.612). The answers choices to these variables use a Likert scale of 1-5, from strongly disagree, disagree, moderately agree or neutral, agree, to strongly agree. The use of a Likert scale can allow respondents to express feelings in approval of a statement. Then the advertising effectiveness variable is the advertisement that can convey the purpose well/right to the target. The advertising effectiveness questionnaire uses a modified EPIC model from Durianto (2003), which consists of 12 questions (Cronbach's alpha 0.619) which are answered on a Likert scale of 1-5 and divided into four dimensions, namely: (1) Empathy dimension; 2) the dimension of persuasion; (3) Impact dimensions; (4) communication dimension. Furthermore, the instant coffee consumer behaviour variable modified from Sumarwan (2011) consists of four question items by measuring the frequency of drinking coffee as a calculation reference.

\section{Analysis}

The data were processed through the process of editing, coding, scoring, data entry, data cleaning, and data analysis using Microsoft Excel and Statistical Product and Service Solution (SPSS) programs. The program was used to analyse the relationship between gender and lifestyle, gender with advertising effectiveness, and gender with instant coffee consumption using the chi-square test. It is also used to analyse respondents' characteristics, lifestyle, and the effectiveness of instant coffee advertisements on instant coffee consumption.

\section{Findings}

\section{Characteristics of Respondents}

All respondents in this study amounted to 100 farmers in Cibungbulang District who had drunk instant coffee and had seen instant coffee advertisements (Iwan Fals edition) within the last 12 months. The study results found that $58 \%$ of respondents were in early adulthood, 38\% were in young adulthood, and the remaining 4\% were in advanced age. The education of the respondents was the lowest for two years (grade 2 elementary school) and the highest for 12 years (graduated from high school), with an average education of 6 years for the respondent (graduated from elementary school). In addition, the income of the respondents in this study ranged from Rp. 500.000 to $\mathrm{Rp}$. 3.000.0000 in one month with an average income per month of Rp. 1.495.000.

\section{Lifestyle}

The results showed that the highest lifestyle (32\%) was the maker's lifestyle. Almost majority of the respondents liked instant coffee as a practical product and preferred the functional value of the product to luxury. Meanwhile, respondents with large incomes tend to think and read books or news activities (2\%) (Table 1). 
Table 1 Distribution of respondents based on lifestyle

\begin{tabular}{lrr}
\hline Type of Lifestyle & $\mathbf{n}$ & $\mathbf{\%}$ \\
\hline Fulfilleds & 2 & 2.0 \\
Believers & 25 & 25.0 \\
Achievers & 7 & 7.0 \\
Strivers & 24 & 24.0 \\
Experiences & 10 & 10.0 \\
Makers & 32 & 32.0 \\
\hline Total & 100 & 100.0 \\
\hline
\end{tabular}

\section{Instant Coffee Advertising Effectiveness (Iwan Fals edition)}

Instant coffee product advertisements are specifically determined as a measuring tool to measure advertising effectiveness. There are many methods to measure the effectiveness of an advertisement, one of which is the EPIC model, this model aims to determine the impact of advertising communications on consumers. There are four dimensions in this EPIC model, namely empathy, persuasion, impact, and communication (Table 2).

Table 2 Distribution of respondents based on the empathy dimension answers

\begin{tabular}{|c|c|c|c|c|c|c|c|}
\hline No & Empathy Dimension & SA & D & $\mathbf{N}$ & $\mathbf{A}$ & SA & $\mathbf{n}$ \\
\hline 1 & $\begin{array}{l}\text { I think the instant coffee } \\
\text { television commercial (Iwan } \\
\text { Fals edition) has gone well }\end{array}$ & 0 & 0 & 10 & 89 & 1 & 100 \\
\hline 2 & $\begin{array}{l}\text { I like instant coffee } \\
\text { television commercials } \\
\text { (Iwan Fals edition) }\end{array}$ & 0 & 0 & 6 & 73 & 21 & 100 \\
\hline 3 & $\begin{array}{l}\text { In my opinion, instant coffee } \\
\text { television commercials } \\
\text { (Iwan Fals edition) have } \\
\text { high appeal }\end{array}$ & 0 & 11 & 72 & 15 & 2 & 100 \\
\hline
\end{tabular}

The results showed that almost all respondents agreed about the perceived effectiveness of the advertisement running well, and this instant coffee advertisement (Iwan Fals edition) was preferred because it had a high appeal to consumers. However, less than $<50 \%$ of respondents do not like instant coffee advertisements (Iwan Fals edition). Figure 2 shows that the advertisement is included in the effective category (3.71), analysing the dimensions of empathy in instant coffee advertisements (Iwan Fals edition). That means that these advertisements can provide interesting information and messages that consumers like.

The results in Table 3 show that more than half of the respondents agree that the instant coffee advertisement (Iwan Fals edition) has succeeded in encouraging and convincing them to buy and consume it. The dimension of persuasion provides what information an advertisement can provide to increase or strengthen the character of a brand. The analysis of the dimensions of persuasion in instant coffee advertisements (Iwan Fals edition) shows that these advertisements are included in the quite effective category (3.14). This shows that the advertisement is sufficient to increase and strengthen the character in the minds of consumers and has an impact on the consumer's desire to buy the product even though it is not maximised (Figure 2). 
Table 3 Distribution of respondents based on the answer to the dimension of persuasion

\begin{tabular}{llrrrrrr}
\hline No & Dimension of persuasion & SA & D & N & A & SA & n \\
\hline 1 & $\begin{array}{l}\text { Instant coffee television } \\
\text { commercials (Iwan Fals }\end{array}$ & 0 & 16 & 10 & 74 & 0 & 100 \\
edition) succeeded in \\
convincing you to buy and \\
consume
\end{tabular}$\quad \begin{array}{lllll} \\
\text { Instant coffee television } \\
\text { commercials (Iwan Fals } \\
\text { edition) succeeded in } \\
\text { convincing you to buy and } \\
\text { consume instant coffee } \\
\text { products instead of trying } \\
\text { hard products }\end{array}$

The study results in Table 4 show that almost all respondents agree that the instant coffee advertisement they see can attract attention until they recognise the existence of the instant coffee product (Iwan Fals edition).

Table 4 Distribution of respondents based on the answers to the dimensions of impact

\begin{tabular}{llrrrrrr}
\hline No & Dimensions of Impact & SD & D & N & A & SA & n \\
\hline 1 & $\begin{array}{l}\text { Instant coffee television } \\
\text { advertisement (Iwan Fals } \\
\text { edition) has successfully }\end{array}$ & & 2 & 11 & 86 & 1 & 100 \\
caught your attention & & & & & & \\
$\begin{array}{l}\text { You know and are familiar } \\
\text { with coffee products from } \\
\text { the television advertisement } \\
\text { for instant coffee (Iwan Fals } \\
\text { edition) }\end{array}$ & 0 & 3 & 1 & 95 & 1 & 100 \\
3 & & & & & \\
$\begin{array}{l}\text { Instant coffee television } \\
\text { commercials (Iwan Fals } \\
\text { edition) are more creative } \\
\text { than television commercials; } \\
\text { the products are trying hard }\end{array}$ & 0 & 12 & 54 & 28 & 6 & 100 \\
\hline Note. SD= Strongly Disagree; D= Disagree; N=Neutral; A=Agree; SA= Strongly Agree & & & \\
\hline
\end{tabular}

Some respondents also felt that the instant coffee advertisement (Iwan Fals edition) was more creative than other coffee advertisements. This means that the advertisement is included in the effective category (3.69) and is more prominent than other brands in the same category. The advertisement can involve consumers in the message conveyed (Figure 2)

The study results in Table 5 show that almost all respondents agree that the delivery of advertisements using a distinctive slogan is visible and following the products offered. However, there are still $<50 \%$ of respondents who do not agree that this instant coffee advertisement (Iwan Fals edition) is more prominent than others and does not explain the function or benefits of consuming the product. Related to the communication dimension analysis results on instant coffee advertisements (Iwan Fals edition), the advertisements are included in the effective category (3.62). Instant coffee advertisements (Iwan Fals edition) can make consumers remember the main message and increase consumer understanding and remember the message conveyed (Figure 2). 
Table 5 Distribution of respondents based on the answers to the communication dimension

\begin{tabular}{|c|c|c|c|c|c|c|c|}
\hline No & Communication Dimension & SD & $\mathbf{D}$ & $\mathbf{N}$ & $\mathbf{A}$ & SA & $\mathbf{n}$ \\
\hline 1 & $\begin{array}{l}\text { Instant coffee television advertisement (Iwan } \\
\text { Fals edition) conveys a clear view }\end{array}$ & 0 & 1 & 3 & 92 & 4 & 100 \\
\hline 2 & $\begin{array}{l}\text { Instant coffee television commercials (Iwan } \\
\text { Fals edition) are more prominent than } \\
\text { television commercials where the products } \\
\text { work hard }\end{array}$ & 2 & 9 & 68 & 21 & 0 & 100 \\
\hline 3 & $\begin{array}{l}\text { Instant coffee television advertisement (Iwan } \\
\text { Fals edition) describes the functions, benefits, } \\
\text { and reasons for choosing instant coffee } \\
\text { products (Iwan Fals edition) over other } \\
\text { products }\end{array}$ & 3 & 21 & 20 & 53 & 3 & 100 \\
\hline 4 & $\begin{array}{l}\text { The slogan of instant coffee (Iwan Fals } \\
\text { edition) is suitable and in accordance with the } \\
\text { products offered and supports the marketing } \\
\text { of these products }\end{array}$ & 1 & 0 & 7 & 75 & 17 & 100 \\
\hline
\end{tabular}

\section{EPIC Models}

Creating an EPIC model is by calculating the effectiveness value using a simple tabulation analysis. The results of simple tabulation analysis in the form of averages are grouped into five groups, namely (1) the average value of $1-1.80$ (very ineffective); (2) the average value is 1.81-2.60 (not effective); (3) the average value is 2.61-3.40 (quite effective); (4) the average value is $3.41-4.20$ (effective); (5) the average value is $4.21-$ 5.00 (very effective). In this study, 23 respondents were included in the quite effective category (2.61 - 3.40), and as many as 77 respondents were included in the effective category $(3.41-4.20)$.

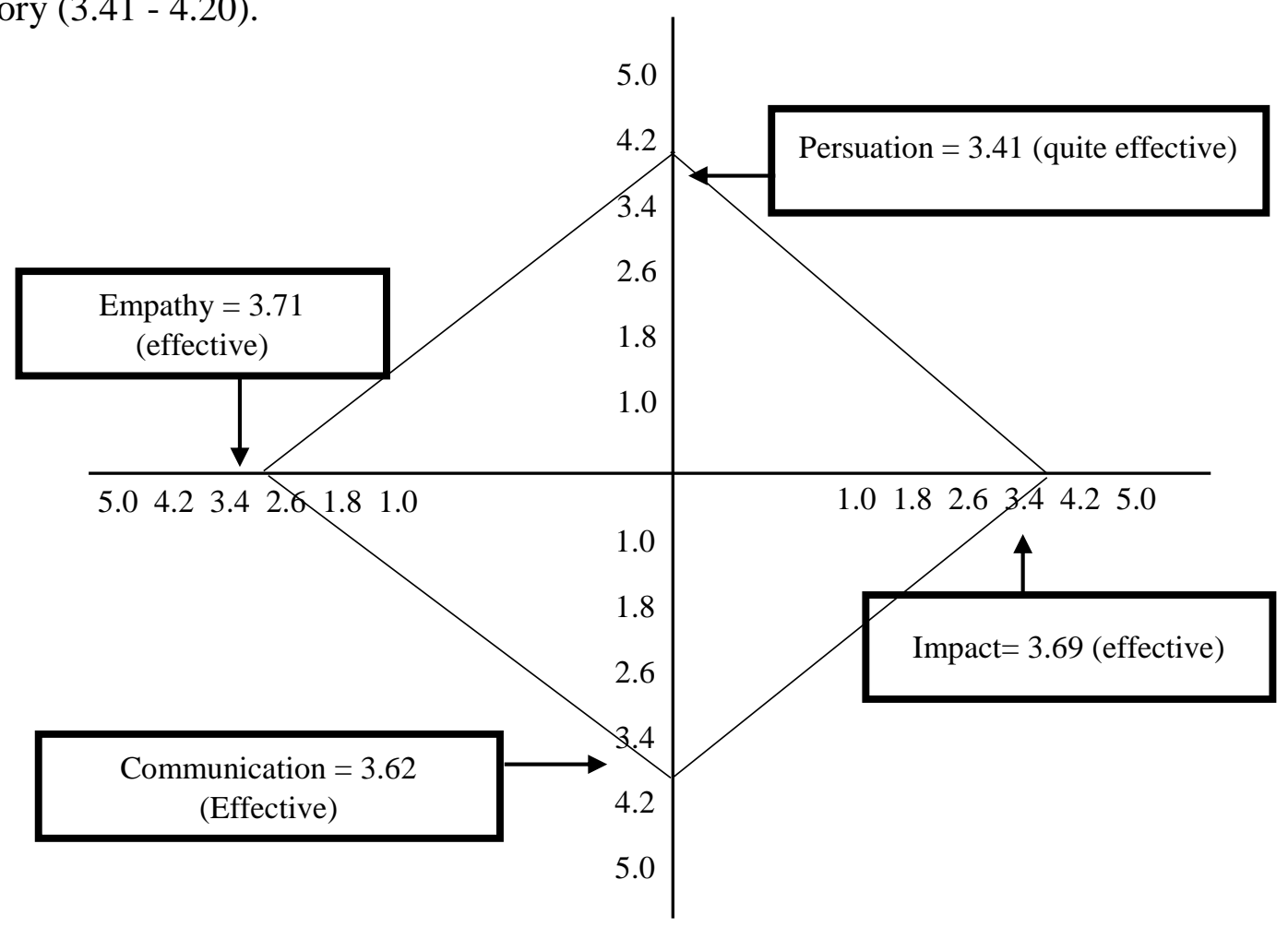

Figure 2 EPIC model of instant coffee advertisement (Iwan Fals edition) 
The results show 3.54 or in the category of effective advertising. The greatest effectiveness of the instant coffee advertisement (Iwan Fals edition) is obtained from the empathy dimension, which is 3.71. This shows that the performance of instant coffee advertisements (Iwan Fals edition) has been going well. Namely, instant coffee advertisements can convey advertising objectives that are following the target. The area in the EPIC model shows the overall effectiveness of advertising. The larger the model area, the higher the advertising effectiveness, and conversely, the smaller the model area, the lower the advertising effectiveness (Figure 2).

\section{Consumption}

Consumption in this study includes the amount of instant coffee consumed per day, the frequency of consuming instant coffee (Iwan Fals edition) per week, the reasons and places for consuming instant coffee.

a. Amount of consumption. The results showed that most (41\%) of the respondents consumed instant coffee twice a day. As many as $32 \%$ of respondents consume instant coffee three times per day, $7 \%$ consume instant coffee more than three times per day, and $20 \%$ consume coffee once a day. The amount of consumption in this study is the quantity of instant coffee consumption of any brand in cups per day.

b. Frequency of consumption. The frequency of instant coffee consumption (Iwan Fals edition) is divided into three categories. First, farmers drink instant coffee (Iwan Fals edition) at most (43\%) twice a week. In addition, 19\% of farmers drink instant coffee, instant coffee (Iwan Fals edition) once a week, and 38 farmers three times a week.

c. Reasons and place. In this study, respondents consume instant coffee to increase energy by $90 \%$, and the remaining $10 \%$ consume instant coffee to refresh the body. The practical nature of instant coffee causes instant coffee to be consumed in several places such as homes, rice fields, or patrol posts. The results show that most $(86 \%)$ of respondents consume instant coffee at home, the rest (14\%) consume instant coffee at the patrol post.

\section{Relationship Between Variables}

The results of the Pearson correlation test showed that the lifestyle of believers had a significant positive relationship $(\mathrm{r}=0.452 * *)$ with instant coffee consumption behaviour. This means that the higher the lifestyle of farmers believers, the farmer's consumption of instant coffee will increase. In addition, the lifestyle of strivers also has a significant positive relationship $\left(\mathrm{r}=0.305^{* *}\right)$ with instant coffee consumption behaviour. This means that the higher the lifestyle of a farmer, the higher the consumption of instant coffee. Table 6 presents data on the correlation between age, education, income, type of lifestyle, and advertising effectiveness on instant coffee consumption. 
Table 6 Relationship between age, education, income, lifestyle and advertising effectiveness with instant coffee consumption

\begin{tabular}{lrr}
\hline Variable & Pearson correlation & Sig \\
\hline Age & 0.153 & 0.128 \\
Education & -0.048 & 0.634 \\
Income & -0.065 & 0.521 \\
Fulfilleds & 0.071 & 0.484 \\
Believers & $0.452^{* *}$ & 0.000 \\
Achievers & 0.179 & 0.075 \\
Strivers & $0.305^{* *}$ & 0.002 \\
Experiencers & 0.057 & 0.572 \\
Makers & 0.018 & 0.857 \\
Advertising effectiveness & 0.080 & 0.429 \\
\hline Note. ${ }^{*}$ significant at the 0.05 level; **significant at 0.01 . level & &
\end{tabular}

\section{Analysis of the Effect of Characteristics, Lifestyle, and Effectiveness of Advertising on Instant Coffee Consumption}

Table 7 shows that gender has a significant effect $(\beta=0.722)$ on instant coffee consumption. It means that the level of instant coffee consumption for men is higher than for women. In addition, the lifestyle of believers has a significant positive effect ( $\beta=$ 0.200 ) on the behaviour of instant coffee consumption. It means that a believer's lifestyle will increase instant coffee consumption behaviour. The adjusted $\mathrm{R}$ square value of 0.287 indicates that the variables studied explain $28.7 \%$ of the variable consumption behaviour. The remaining $71.3 \%$ is explained by other variables not studied.

Table 7 The effect of respondents' characteristics, lifestyle and advertising effectiveness on instant coffee consumption

\begin{tabular}{lrrr}
\hline Variabel & $\begin{array}{r}\text { Non-standardised } \\
\text { coefficient } \boldsymbol{\beta}\end{array}$ & $\begin{array}{r}\text { Standardised } \\
\text { coefficient } \boldsymbol{\beta}\end{array}$ & Sig. \\
\hline Gender & 0.722 & 0.395 & $0.000^{* *}$ \\
Age & 0.002 & 0.031 & 0.753 \\
Education & -0.024 & -0.073 & 0.437 \\
Income & -1.357 & -0.087 & 0.337 \\
Advertising & 0.017 & 0.016 & 0.860 \\
effectiveness & & & \\
Fulfilleds & -0.070 & -0.094 & 0.310 \\
Believers & 0.190 & 0.331 & $0.001^{* *}$ \\
Achievers & 0.041 & 0.045 & 0.670 \\
Strivers & 0.014 & 0.035 & 0.757 \\
Experiencers & 0.114 & 0.159 & 0.151 \\
Makers & -0.042 & -0.053 & 0.871 \\
\hline F & & & \\
Adjusted R square & & 0.4983 & \\
\hline Note. ${ }^{*}$ significant at the 0.05 level; **significant at 0.01 level & 0.287 &
\end{tabular}




\section{Discussion}

This study aims to analyse the lifestyle and advertising effectiveness of instant coffee consumption among peri-urban farmers. Instant coffee (Iwan Fals edition) is the product studied and the influence of advertising in consuming coffee. This study indicates that farmers consume coffee from various ages, namely early adulthood, young adults, and old adults. Respondents of varying ages are farmers who are still productive in farming, namely farmers who work for six hours (6 am to 12 noon) with an average Rp. 50.000 per day.

In addition, other results show that farmers' relationship with instant coffee consumption is very close. Farmers' drinking instant coffee is almost every day and has become their favourite drink after water or tea. This is in line with SWA (2010) and AEKI (2013) research that coffee has become the third-largest beverage consumed by the world community, instant coffee consumption in Indonesia, which also experiences growth every year. Instant coffee is produced due to changes in people's consumption patterns from traditional to more practical consumption patterns (Mifzar \& Sinaga, 2015). According to the Ministry of Tourism (2016), instant coffee produced by the company uses many types of robusta and arabica coffee as raw materials, such as instant coffee brand coffee (Iwan Fals edition) made from a mixture of the two types of coffee.

A peri-urban area (suburb) is an area that has experienced changes in land use marked by the shift in the function of fertile land used for residential or industrial activities. The entire area of Bogor Regency is a peri-urban area, one of the sub-districts included in the peri-urban area is Cibungbulang District. Based on Andriamsari (2015) that Cibungbulang District is still included in the peri-urban category with the following characteristics: (1) Supporting food security in the Bogor City and DKI Jakarta areas; (2) High population density; (3) The threat of largely agricultural land conversion. In addition, many respondents work as farmers (sweet potato, rice, and vegetable farmers), so they often choose instant coffee as a drink to increase energy. This makes coffee consumption very important for farmers because if they do not consume instant coffee in one day, farmers will feel weak or dizzy.

This is in line with Rahmawati (2013) research, which says that, in general, a person will choose a beneficial product. In addition, consuming instant coffee as an energyboosting drink is carried out when processing agricultural land and when returning from agricultural land. This can make you feel more energetic and enthusiastic when you have consumed instant coffee even though you have not consumed rice or other carbohydrate sources or just to refresh the body. Refreshing the body in question is that the respondent drinks coffee only to refresh the body so that it is not sleepy and is consumed when relaxing or hanging out with friends. In line with Fatimah (2013), some people drink coffee while doing business activities, or as a tool to stay in touch with colleagues or family, or just relax and hang out with friends.

This study also discussed the frequency (per week) and the amount (per day) of instant coffee consumption, the place, and the reasons for consuming coffee. The results show that farmers consume instant coffee on average before going to the fields and after going to the fields (twice per day). However, the consumption patterns of farmers in periurban areas have never consumed instant coffee in the fields or fields because the distance between the fields or fields and the respondent's house is not far, so respondents prefer to consume at home. On the other hand, consuming instant coffee (Iwan Fals edition) twice 
a week was also found in this study. This is because, in one week, they consume various brands of instant coffee.

In this regard, that overall, places to consume instant coffee are mostly done at home. This is following Meliala (2017) research that respondents with an income of less than four million consume instant coffee at home. Consuming instant coffee at home has become a habit when going out and returning from farming. Respondents no longer drink instant coffee in rice fields because the distance is not too far, and working time is only until noon. Meanwhile, the patrol post is another convenient place to consume instant coffee because it is with friends.

The results of the chi-square test show that male farmers consume more instant coffee than women. This is in line with Bistara and Kartini's research (2018) which states that gender has a relationship with coffee drinking habits, where the intended gender is male. Besides that, the lifestyle of male farmers tends to be on the side of the makers in consuming instant coffee because they like practical things and feel they will get energy after consuming instant coffee. Male respondents highly favour the practicality of consuming instant coffee because male respondents can make instant coffee independently with this convenience. Moreover, the instant coffee making time is not long. According to Putristates that products, men like practical, easy, and comfortable in purchasing products things. In addition to practicality, the male respondent requires a lot of energy to work on agricultural land. Therefore, consuming instant coffee can increase energy and enthusiasm to work on agricultural land.

The relationship test results show a positive relationship between the believer's lifestyle and the strivers' lifestyle and the consumption of instant coffee. This means that the believer's and the strivers' lifestyles are both owned by respondents with low economic resources, and both have the same desire, namely wanting to consume coffee. However, there are differences in the brand of coffee purchased. Farmers with a strivers lifestyle tend to buy instant coffee, which is expensive and try new brands. Meanwhile, farmers with a believing lifestyle tend to buy instant coffee brands that have been known before. In addition, the relationship between advertising effectiveness and instant coffee consumption does not have a significant relationship. This is pre-sumably because farmers do not drink instant coffee (Iwan Fals edition) regularly every day. Instead, farmers drink instant coffee with various brands in one week. However, age, education, and income have no relationship with instant coffee consumption because farmers consume instant coffee has become a habit and does not depend on age, education, or income.

Meanwhile, the influence test results show that two factors encourage farmers to consume instant coffee. The first factor is gender, and the second factor is believing in lifestyle. Male gender affects instant coffee consumption, and male farmers consume more instant coffee than female farmers. This follows Mizfar and Sinaga (2015) research, which states that men mostly consume instant coffee. The second factor is a lifestyle of belief which has a positive influence on instant coffee consumption. This is following the fact that farmers consume instant coffee because it has become a habit that has been carried out for a long time. Even though income conditions are weak, farmers still consume instant coffee. This is in line with Willbanks' research (2005) which states that a person with a believing lifestyle will tend to have a traditional mindset, have weak resources, focus on principles, find it difficult to adapt to new things, have a routine that tends to remain for the long term. Time and usually, this lifestyle is found in rural communities. 
In addition, the results of the EPIC model show that farmers have received overall instant coffee advertisements (Iwan Fals edition) in terms of empathy, impact, and communication. However, it is not so maximally accepted by farmers in terms of persuasion. This is in line with previous research conducted by Budiarti et al. (2013), which states that in measuring instant coffee advertisements with the EPIC model, a partial part has not been maximised, namely the dimension of persuasion. Consumption of instant coffee (Iwan Fals edition) in this study showed the average result of farmers consuming twice a week. This is because farmers drink coffee with various brands in one week, not only instant coffee brands (Iwan Fals edition). Therefore, in line with the results of the analysis of the EPIC model on the dimension of persuasion, it does not run optimally. Meanwhile, the limitation of this research is the instant coffee advertisement (Iwan Fals edition) which last aired about 12 months ago. In addition, the sampling technique was carried out purposively so that the research results could not be generalised to various respondents.

\section{Conclusions and Recommendations}

\section{Conclusions}

The results of research conducted on peri-urban farmers in Bogor Regency show that more than one-third of the respondents have a maker lifestyle with an effective value of instant coffee advertising. As many as $43 \%$ of respondents drink instant coffee twice a week. In addition, almost all farmers drink instant coffee at home to increase energy. This study also found a relationship between the male gender, a lifestyle of believers, and a lifestyle of trying hard (strivers) with instant coffee consumption. In addition, this study also shows that male gender and lifestyle believers affect instant coffee consumption.

\section{Recommendations}

Future research is expected to analyse the effectiveness of advertising based on its dimensions on instant coffee consumption. In addition, it can involve the family characteristics of the respondents to determine the effect of family characteristics on consumption. It was using other brands of instant coffee advertisements that are currently airing on television. In addition, further research can involve various jobs in peri-urban villages such as village officials, housewives, traders, or other types of workers.

\section{References}

[AEKI] Asosiasi Exportir dan Industri Kopi Indonesia. (2013). Indonesia coffee market. Retrieved from: http://www.aeki-aice.org.

AC Nielsen. (2008). EPIC model publication. Retrieved from: www.nielsen.com

Andriamsari, H. (2015). Potential and strategies for developing peri-urban agriculture in Bogor Regency. [Theses]. Bogor(ID): Institut Pertanian Bogor

[BPS] Badan Pusat Statistik. (2013). Number of Agricultural Workers. Jakarta(ID): Badan Pusat Statistik.

[BPS] Badan Pusat Statistik. (2017). National Economic Driver. Jakarta(ID): Badan Pusat Statistik 
Bistara, D. N., \& Kartini, Y. (2018). The relationship between coffee consumption habits and blood pressure in young adults. Journal of Vocational Health, 3(1), 23-28. EISSN: 2599-3275.

Budiarti E., Kurniawan A., Achsani A., Purnama D., \& Rosyid F. (2013). The effectiveness of the good day advertising version Is this what it feels like to love television using the EPIC model. Journal of Cakrawala, 8(1), 70-77. Doi: https://doi.org/10.32781/cakrawala.v8i1.223

Durianto, D., Sugiarto, A.W., \& Supratigno, H. (2003). Market Invasion With Effective Advertising Strategies, Programs, and Measurement Techniques. Jakarta(ID): Gramedia Pustaka Utama.

Fatimah, S. (2013). The influence of lifestyle and self-concept on consumer decision making in choosing a coffeeshop in Samarinda. Journal of Management, 1(1), 18.

Hadi, M. P., Wahono, B. (2015). Analysis of the effectiveness of "Top Coffee" advertising with the EPIC Model approach. Management Scientific E-Journal, 4(3), 427-440

Handoko, S. R. (2006). Analysis of the influence of endorser credibility and advertising creativity on the effectiveness of advertising that affects attitudes towards the brand. [Theses]. Semarang(ID): Universitas Dipenegoro.

Hyun, J. L., Hyeon, J. C., Wenwen, X., \& Ann Fairhurst. (2010). The Influence of Consumer Traits and Demographics on Intention to Use Self-service Checkouts. Journal of Marketing Intelligence and Planning, 28(1), 46-58. Doi: http://dx.doi.org/10.1108/02634501011014606

Jung, W. L. (2010). The roles of demographics on the perceptions of electronic commerce adoption. Academy of Marketing Studies Journal, 14(1): 71-89.

[Kemenperin] Kementerian Perindustrian Republik Indonesia. (2013). Coffee processing industry roadmap. Retrieved from agro.kemenperin.go.id.

[Kemenperin] Kementerian Perindustrian Republik Indonesia. (2016). Coffee processing industry roadmap. Retrieved from: agro.kemenperin.go.id.

[Kementan] Kemenetrian Pertanian. (2017). Statistik Perkebunan Indonesia: Kopi. Jakarta(ID): Kementerian Pertanian Republik Indonesia.

Kotler, P., \& Keller, K. N. (2008). Marketing Management. Jakarta(ID): Erlangga. Translated by bob sabran MM.

Lee, M., \& Jhonson, C. (2007). Fundamental Principles of Advertising in a Global Perspective. Jakarta(ID): Kencana.

Meliala, R. R. (2017). Coffee consumption rates by income, age, and price in Depok. [Theses]. Jakarta(ID): UIN.

Mifzar, F., \& Sinaga, A. (2015). Analysis of the factors that influence consumer behavior in making instant coffee purchasing decisions. SEPA Journal (Socio-Economic Agriculture and Agribusiness), 11(2), 175-180. Doi: https://doi.org/10.20961/sepa.v11i2.14172

Mowen \& Minor. (2012). Consumer Behavior Volume I 5th Edition. Jakarta(ID): Erlangga

Patterson \& Paul, G. (2007). Demographic correlates of loyalty in a service context. Journal of Service Marketing, 21(2),112-121. Doi: http://dx.doi.org/10.1108/08876040710737877 
Putrie, N. K. (2016). Differences in motivation to buy fashion products online for men and women at Satya Wacana Christian University. [Theses]. Salatiga(ID): Universitas Kristen Satya Wacana Salatiga

Rahmawati, N. (2013). The effect of using celebrity endorsers in Lux soap advertisements on consumer behavior in Sungai Dama Samarinda Village. Journal of Communication Studies, 1(1), 362-373.

Satyajaya, W., Rangga, A., Nurainy, F., \& Al Rasyid, H. (2014). Consumer decision making process and product attributes of instant coffee. Jurnal Teknologi \& Industri Hasil Pertanian, 19(3), 297-306. Doi: http://dx.doi.org/10.23960/jtihp.v19i3.297\%20-\%20306

Setiadi, N. J. (2008). Consumer Behavior: Concepts and implications for marketing strategy and research. Jakarta(ID): Kencana

Setyawan, I. (2014). Analysis of the effectiveness of instant coffee television advertisements TOP COFFEE endorser "Iwan Fals". Business management, 4(1), 39-49. Doi: https://doi.org/10.22219/jmb.v4i1.5279

Simanjuntak, D. F. (2013). Consumer attitudes against top coffee instant powder in Bogor City Area, West Java. [Theses]. Bogor(ID): Institut Pertanian Bogor.

Solikatun, S., Kartono, D. T, \& Demartoto, A. (2015). Coffee Consumption Behavior as a Consumption Community Culture (Phenomenological Study on Coffee Drinkers at Coffee Shops in Semarang City). Journal of Sociological Analysis, 4(1), 60-74. Doi: https://doi.org/10.20961/jas.v4i1.17410

Sumarwan, U. (2011). Consumer Behavior: Theory and Its Application in Marketing 2nd Edition. Jakarta(ID): PT Ghalia Indonesia.

Swastika, K. D. (2012). The effect of coffee on post prandial blood sugar levels in seventh semester students of the USU Faculty of Medicine in 2012. [Theses]. Medan(ID): Univesitas Sumatera Utara.

[SWA] SWA majalah digital. (2010). Tren kopi. 1-3.

Tjiptono, F., Chandra, G., \& Adriana, D. (2008). Strategic Marketing. Yogyakarta(ID): Andi.

Umar, H. (2003). Strategic Marketing Service Consumer Behavior Research Methods. Jakarta(ID): Ghalia Indonesia

Upphaswara, A. M. (2014). Analysis of competition map of sachet instant coffee products in Bogor City. [Theses]. Bogor(ID): Institut Pertanian Bogor.

Wadi, H., \& Rahanatha, G. B. (2013). The relationship between demographic variables and consumer responses to advertisements for top coffee brand coffee products in Denpasar City. Udayana University Management E-Journal, 2(9), 1036-1052. EISSN: 2302-8912.

Willbanks, J. K. (2005). Exploring lifestyle orientation. Attitude toward lifestyle merchandising, and attitude toward lifestyle advertising as presdictor of behavioral intention to purchase lifestyle home furnishing product. [Theses]. Texas(US): Uniedisity of North Texas.

Yulisa, L., Indriani, Y., \& Situmorang, S. (2013). The consumption behavior of Lampung University students towards instant ready-to-eat ground coffee. Journal of Agribusiness Sciences, 1(4), 326-333. Doi: http://dx.doi.org/10.23960/jiia.v1i4.326-333.

Yunianto A. E. (2015). Knowledge, lifestyle, and nutritional status and their relation to blood glucose status in rural men and women. [Theses]. Bogor(ID): Institut Pertanian Bogor. 